\title{
STRENGTHENING THE ROLE OF PARENTS IN ACCOMPANYING ELEMENTARY SCHOOL STUDENTS TO USE GADGETS DURING THE COVID-19 PANDEMIC
}

\author{
Eka Oktavianingsih ${ }^{{ }^{*}}$ \\ ${ }^{1 *}$ Department of Early Childhood Education, Universitas Trunojoyo Madura, Bangkalan, \\ Indonesia
}

eka.oktavianingsih@trunojoyo.ac.id, http://orcid.org/0000-0002-3154-9413

DOI: https://doi.org/10.21107/Widyagogik/v8i2. 9648

Received November 04, 2020; Revised December 10, 2020; Accepted January 21, 2021

\section{Abstract}

The school from home (SFH) policy during the COVID-19 pandemic has an impact on the routine activities of elementary students at home. Prior to COVID-19, the time spent by elementary school children using gadgets ranged from 1 to 2 hours per day, while during SFH elementary students could spend at least 4 hours per day. The increasing intensity and frequency of gadget use among elementary school students makes the role of parents important in accompanying children. Of course, the role of parents is needed so that children can use gadgets wisely to support educational goals, not just for entertainment purposes. The purpose of this study is to strengthen the role of parents in assisting elementary school children to use gadgets during the COVID-19 pandemic through outreach and mentoring activities. The subjects involved were 30 parents who have elementary school children in Porodeso Village, Sekaran District, Lamongan Regency. The method of implementation uses face-to-face techniques (with health protocols), door to door, and online (online using whatsapp group). Based on the results of interviews with parents after participating in the program, it shows that most parents have understood and implemented the gadget assistance material for children. The principles of gadget assistance for elementary school children include: exemplary, agreement, consistency, and serenity.

Keywords - Pandemic, Gadget, Students, Elementary, Parents. 
62 Strengthening The Role of Parents in Accompanying Elementary School Students to Use Gadgets During The Covid-19 Pandemic

Eka Oktavianingsih

\section{Introduction}

Since early March 2020, Indonesia has been hit by problems related to the entry of the COVID-19 virus which initially appeared in Wuhan, China. Coronavirus is an RNA virus with a particle size of 120-160 nm which mainly infects animals (bats and camels) and can be transmitted from human to human (Susilo et al., 2020). The entry of the virus into Indonesia certainly has an impact on various sectors of life including health, economy, social, technology, culture and education. Since the stipulation of the COVID19 pandemic conditions in Indonesia, on March 24, 2020 the government through the Minister of Education and Culture of the Republic of Indonesia issued Circular Letter Number 4 of 2020 (Surat Edaran Nomor 4 Tahun 2020) concerning Implementation of Education Policies in an Emergency for the Spread of COVID-19. Through this Circular, the government calls on the learning process to be carried out at home through learning/distance learning to provide meaningful learning experiences for students. Besides aiming to minimize the chain of spread of COVID-19, online learning aims to keep teaching and learning activities running amid the corona pandemic.

School From Home (SFH) or learning from home is carried out from the level of Early Childhood Education to Higher Education. Learning from home has other terms such as distance learning, online learning, online learning, and virtual learning (Sun \& Chen, 2016). Online/distance learning is a learning process using internet networks and IT devices. Online learning also provides opportunities for students in terms of flexibility in time and place. This learning also gives students the opportunity to interact with their teachers through various applications such as classrooms, video converence, telephone or live chat, zoom or via WhatsApp groups even though they are in different places (Dewi, 2020).

Elementary school student activities during the pandemic have been limited to only indoors by doing online learning, without being able to interact with friends or other people outside the home. Most students will spend their spare time using their gadgets to watch videos, play games, play social media, and so on. In fact, according to the GSMA (2014) the use of gadgets in about $22 \%$ of children will reduce time with family, even time to complete school assignments. In addition, $10 \%$ of children use gadgets to forget to eat and sleep, and $38 \%$ of children feel restless when they can't use the internet. Based on research conducted by Syifa, Setianingsih, \& Sulianto (2019) on fifth grade elementary school children who use gadgets, it shows that there is a negative impact from the use of gadgets. The negative impact affects emotional and moral development, where children become irritable, disobedient, imitate behavior, talk to themselves with gadgets, lack discipline, become lazy to do anything, abandon the obligation to worship, and reduce learning time due to playing too many games and watch youtube. In this study, the duration of the use of gadgets by children was around 2 hours with the conditions before the COVID-19 pandemic.

In Porodeso Village, Sekaran District, Lamongan District, based on interview data and questionnaires, it shows that as many as 12 from 16 elementary school students use gadgets with a duration of more than 2 hours per day. 5 of them even spend more 
than 5 hours a day playing gadgets. The impacts that arise due to the consumption of gadgets include children becoming lazy to study, forgetting time, carrying gadgets wherever they go, becoming more individualistic, and becoming irritable. The restrictions imposed by parents are in the form of verbal, physical warnings, and sometimes they are forced to hide their gadgets and not fill in the data quota on children's gadgets.

According to Suwarsi (Chusna, 2017), gadget addiction in elementary school student was characterized by: (1) when preoccupied with gadgets, children lose interest in other activities, (2) children become less fond of socializing or playing outside the home with their peers, (3) children tend to nag and get angry when disturbed or reprimanded when using gadgets, and (4) children dare to lie or steal time to play gadgets. Given the huge negative impact when children are addicted to gadgets, it is necessary to have proper assistance when children use gadgets. Proper assistance needs to be done by parents as the child's first and foremost teacher when they are at home. Parents have a role to supervise, assist, and limit the use of gadgets, as well as deviant children's behavior (Syifa et al., 2019). The role of parents in mentoring is influenced by several factors, including knowledge about the benefits and risks of using devices in children and the limited time for parents in mentoring (Irmayanti, 2018). Based on initial studies and also previous research by Fedina et al., (2017) parents both in villages and cities still have low awareness and knowledge in accompanying children to use gadgets to support learning activities.

Most parents in Porodeso Village, Sekaran Subdistrict who have children in elementary school and Madrasah Ibtidaiyah still do not know the risks of using gadgets and the appropriate forms of assistance. Therefore, researchers intend to conduct community service research with the title "Strengthening the role of parents in assisting elementary school children to use gadgets during the COVID-19 pandemic". The purpose of this community service is for parents to understand and implement appropriate assistance to children who use gadgets during the COVID-19 pandemic.

\section{Method}

Community service research activities carried out by researchers are in the form of training and mentoring aimed at parents who have elementary school age children in Porodeso Village, Sekaran District, Lamongan Regency. Because it is still in a COVID-19 pandemic condition, various methods of implementation are carried out, including:

a. Face to face training (taking into account health protocols).

b. Door to door at each house (distributing brochures \& assistance by observing health protocols).

c. Online training using the whatsapp group. 
64 Strengthening The Role of Parents in Accompanying Elementary School Students to Use Gadgets During The Covid-19 Pandemic

Eka Oktavianingsih

This community service activity also involved 4 students who live around the service location. The schedule for the implementation of research and community service activities is illustrated in table 1.

Table 1. Implementation Schedule

\begin{tabular}{|l|l|l|l|l|l|l|l|l|}
\hline \multirow{2}{*}{ No. } & \multicolumn{5}{|c|}{ Activity } & \multicolumn{5}{c|}{ Week } \\
\cline { 5 - 8 } & & I & II & III & IV & V & VI & VII \\
\hline 1. & Site survey & & & & & & & \\
\hline 2. & Need assement from society & & & & & & & \\
\hline 3. & $\begin{array}{l}\text { Preparing for implementating } \\
\text { a counseling }\end{array}$ & & & & & & & \\
\hline 4. & $\begin{array}{l}\text { Implementating a face to face } \\
\text { counseling }\end{array}$ & & & & & & & \\
\hline 5. & Implementating a door to door & & & & & & & \\
\hline 6. & $\begin{array}{l}\text { Implementating an online } \\
\text { counseling }\end{array}$ & & & & & & & \\
\hline 7. & Compiling a report & & & & & & & \\
\hline
\end{tabular}

The in-depth interviewed technique was used in this study to obtained the data of parent's responses to this program. Beside that, the purpose was to find the opened problems/responses (Siswanto \& Suyanto, 2018). From a total of 30 respondents, there were 5 respondents who were interviewed in-depth about what they had mastered after participating in the training program.

\section{Result and Discussion}

This community service program is carried out based on the main problems experienced by most parents in Porodeso Village, Sekaran District, Lamongan Regency, namely they do not understand the impact of using gadgets on students and do not understand how to provide proper assistance to students when using gadgets. This problem was obtained through open interviews with 15 parents of elementary school students in Porodeso Village. Departing from these problems, the team then decided to develop a parental role strengthening program that aims to make parents wisely assist and supervise their children in using gadgets. The parenting program is manifested in 3 (three) activities including: face-to-face counseling, door-to-door, and online counseling. 


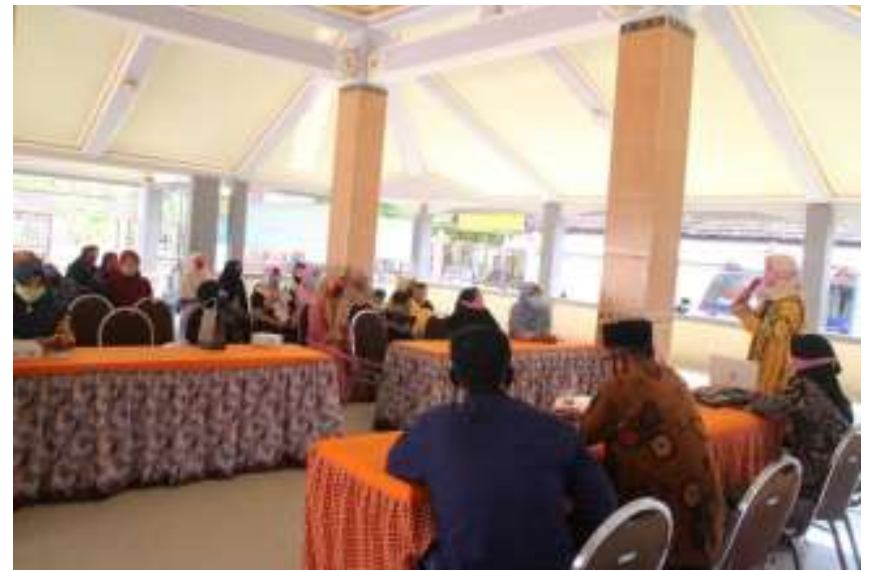

Picture 1. face to face counseling using health protocols.

Face-to-face counseling is conducted for one (1) day on Saturday 12 September 2020 at 13.00 WIB up to 15.30 WIB. The face-to-face counseling activity was attended by 30 parents who have elementary school (Madrasah Ibtidaiyah) children in Porodeso Village. The material presented in face-to-face counseling activities includes: understanding of gadgets, gadget functions, negative impacts of gadgets, signs of children being addicted to gadgets, and general tips to assist children in using gadgets The success of this counseling lies in the understanding and ability of parents to recognize signs of gadget addiction in children and to realize that gadgets can be used wisely. Door to door activities were held on September 14 to 17, 2020 aimed at 10 parents who were randomly selected face-to-face counseling participants. The purpose of this activity is to provide assistance to parents if parents still have problems or difficulties in accompanying their children. In this activity, parents were also given pamphlets containing information about monitoring the use of gadgets in children. Online counseling activities were held on Wednesday, September 23, 2020 through the WhatsApp group application, which was attended by 30 parents who have elementary school (Madrasah Ibtidaiyah) children in Porodeso Village. In this activity, the researcher invited an external resource person who is an educational psychologist so that parents can directly consult about problems and difficulties when assisting their children using gadgets. 
66 Strengthening The Role of Parents in Accompanying Elementary School Students to Use Gadgets During The Covid-19 Pandemic

Eka Oktavianingsih

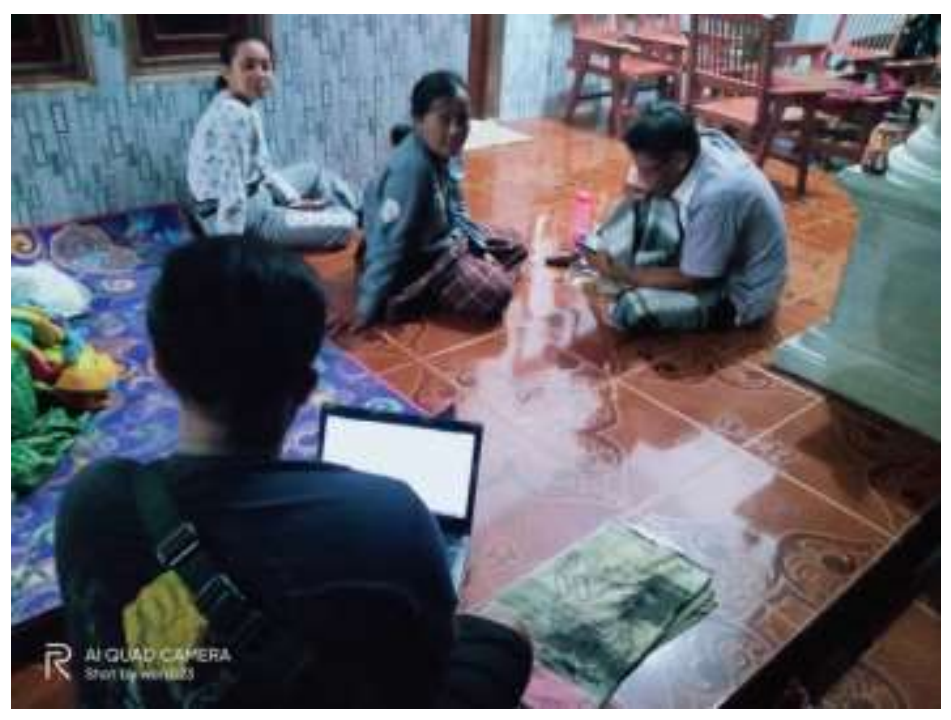

Picture 2. a door to door counseling

The level of success of a program is marked by changes in knowledge, attitudes, and behavior of the participants or target groups. Parents who have participated in counseling about assisting the use of gadgets for elementary school children have implemented the results of the counseling in caring for their children. The changes felt by parents include the addition of knowledge, changes in attitudes and behavior in accompanying children to use gadgets. Following are the results of interviews with 4 participants in the parental role strengthening program.

"Before, I didn't know how to reduce the use of gadgets for my children, but now I understand how to reduce the use of gadgets in children. I also just realized that using gadgets for too long can be addictive in children ...." (Participant 1)

"We as parents are becoming wiser in assisting children using gadgets, especially since this is the first experience since the BDR (Learning From Home) activity, so we need lots of references during this pandemic period ..." (Participant 2)

"I have become more aware of the negative impact of using gadgets on children, and I know more about how to deal with children who are addicted to gadgets ..." (Participant 3)

"After joining this program, I know how to behave when the child only focuses on their gadgets .... " (Participant 4) 
"I now realize that the role of parents in assisting children to use gadgets is also a collaboration between me and my partner. And I am more and more convinced to make an agreement about joint parenting ..... " (Participant 5)

Parents who have participated in this counseling activity will adopt an example in using gadgets wisely. If parents can be ideal parents, especially in using gadgets, then children will also imitate the wisdom of their parents in using gadgets (Fatmawati, 2019). For example, when parents are eating, they should not be playing gadgets. If parents do this, then most likely, children will also imitate. In addition, parents will also apply democratic parenting in minimizing the negative impact of using gadgets. Democratic parenting is characterized by an open attitude between parents and children (Masni, 2016). They will make mutually agreed agreements about when to use gadgets, what gadgets are used for, and other activities/routines that children do besides playing gadgets. The agreements that have been made are then taped and placed in a place that is easily accessible and read by the child. This process gives children the freedom to express their opinions, feelings and desires and can respond to the opinions of parents. Parents will play a role in providing opinions and considerations on the agreement to use the gadget. If this is done, the child will also feel that he is the maker of the agreement so that the commitment to obey it will also be strong.

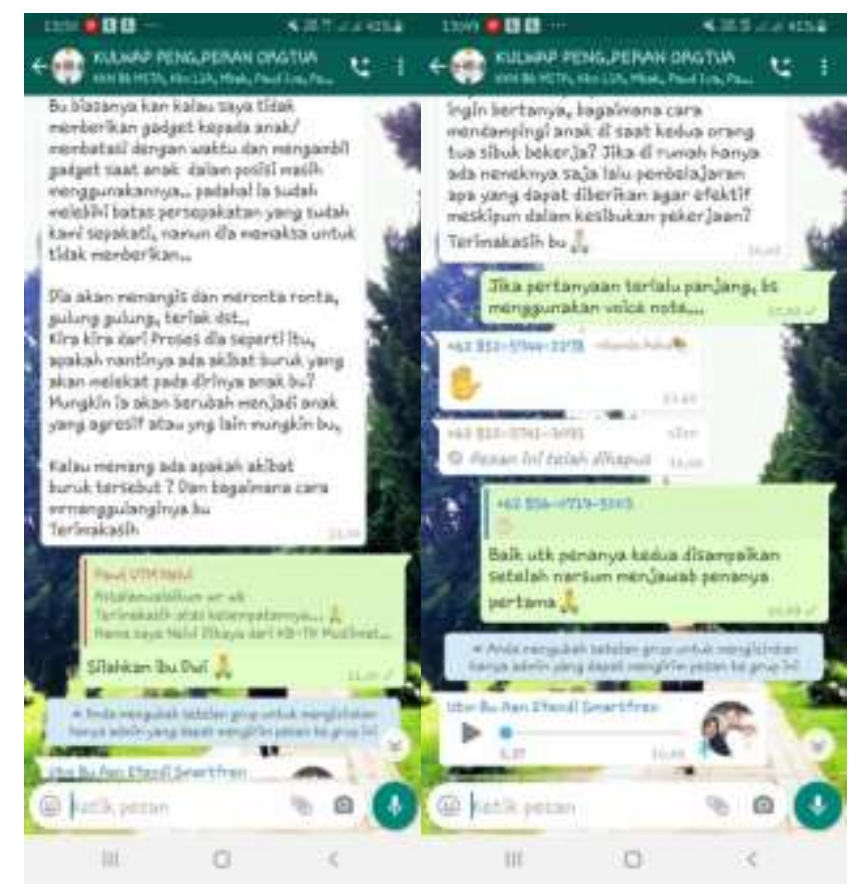

Picture 3. Online training using WhatsApp Group

In carrying out wise assistance to children when using gadgets, parents also need to be consistent and be done with calmness. As stated by Siwi, Krisnawati, Sulistyowati, \& Safitri (2019), the consistency of democratic parenting with child assistance when 
68 Strengthening The Role of Parents in Accompanying Elementary School Students to Use Gadgets During The Covid-19 Pandemic

Eka Oktavianingsih

using gadgets is the main key to prevent gadget addiction in children. This means that parents cannot change in accompanying children, especially in implementing agreements. If a child breaks the agreement, parents must remain calm and communicate to the child about the consequences of breaking the agreement. For example: if the child is given 30 minutes of gadget play time, but the child breaks the time limit of up to 40 minutes, then the child will receive the consequence that the next day the quota for playing gadgets is also reduced by 10 minutes. This consistency is also needed by parents in providing positive examples in using gadgets (Fatmawati, 2019). The smooth running of outreach activities both in person, door to door, and online is also due to the support from stakeholders, in this case the Porodeso village government. The village government supports the provision of infrastructure and verbal reinforcement assistance to parents. This is in accordance with the results of research conducted by Fitroh \& Oktavianingsih (2020) that the attractiveness of the material and the support of stakeholders can maximize the implementation of training activities for the target group, including parents.

\section{Conclusion}

Most parents who have elementary school children in Porodeso Village have experienced changes in knowledge, understanding, attitudes and behavior in accompanying children to use gadgets during the COVID-19 pandemic. Parental assistance is a focus on gadgets that support educational functions, especially children's school from home activities. After participating in the training, parents understand the gadget assistance material for children and implement the principles of gadget assistance to elementary school children, including: exemplary, agreement, consistency, and serenity.

Acknowledgments: The researchers would like to express their gratitude to the Head of Porodeso Village, Sekaran District, Lamongan Regency who has given permission to the implementing team to carry out community service. The team also thanked to LPPM Trunojoyo Madura University for supporting and providing opportunities for this study.

\section{References}

Chusna, P. A. (2017). Pengaruh Media Gadget pada Perkembangan Karakter Anak. Dinamika Penelitian: Media Komunikasi Sosial Keagamaan, 17(2), 315-330. https://doi.org/10.21274/dinamika/2017.17.2.315-330.

Dewi, W. A. F. (2020). Dampak Covid-19 terhadap Implementasi Pembelajaran Daring di Sekolah Dasar. Edukatif: Jurnal Ilmu Pendidikan, 2(1), 55-61.

Fatmawati, N. I. (2019). Literasi Digital, Mendidik Anak Di Era Digital Bagi Orang Tua Milenial. Jurnal Politik Dan Sosial Kemasyarakatan, 11(2), 119-138. https://doi.org/10.1017/CBO9781107415324.004. 
Fedina, N. V., Burmykina, I. V., Zvezda, L. M., Pikalova, O. S., Skudnev, D. M., \& Voronin, I. V. (2017). Study of educators' and parents' readiness to implement distance learning technologies in preschool education in Russia. Eurasia Journal of Mathematics, Science and Technology Education, 13(12), 8415-8428. https://doi.org/10.12973/eimste/80802.

Fitroh, S. F., \& Oktavianingsih, E. (2020). Peran Parenting dalam Meningkatkan Literasi Kesehatan Ibu terhadap Stunting di Bangkalan Madura. Jurnal Obsesi: Jurnal Pendidikan Anak Usia Dini, 4(2), 610-619.

GSMA. (2014). Children's Use of Mobile Phones. Special Report 2014, 9972 LNCS, 523531. https://doi.org/10.1007/978-3-319-46418-3 46

Irmayanti, Y. (2018). Peran orangtua dalam mendampingi penggunaan gawai pada anak prasekolah. Naskah Publikasi, 10(1). https://doi.org/10.1542/peds.2006-2099.

Kemendikbud. (2020). Surat Edaran Nomor 4 Tahun 2020 tentang Pelaksanaan Kebijakan Pendidikan Dalam Masa Darurat Penyebaran COVID-19. Jakarta.

Masni, H. (2016). Peran Pola Asuh Demokratis Prangtua terhadap Pengembangan Potensi Diri dan Kreativitas Siswa. Jurnal IImiah Dikdaya, 6(1), 58-74.

Siswanto \& Suyanto. (2018). Metodologi Penelitian Kuantitatif Korelasional. Klaten: Bosssript.

Siwi, I. N., Krisnawati, M., Sulistyowati, N., \& Safitri, O. R. (2019). Pencegahan kecanduan gadget dan tantrum pada anak melalui konsistensi pola asuh. Jurnal Abdimas Madani, 1(1).

Sun, A., \& Chen, X. (2016). Online education and its effective practice: A research review. Journal of Information Technology Education: Research, 15(2016), 157-190. https://doi.org/10.28945/3502.

Susilo, A., Rumende, C. M., Pitoyo, C. W., Santoso, W. D., Yulianti, M., Herikurniawan, H., ... Yunihastuti, E. (2020). Coronavirus Disease 2019: Tinjauan Literatur Terkini. Jurnal Penyakit Dalam Indonesia, 7(1), 45. https://doi.org/10.7454/ipdi.v7i1.415.

Syifa, L., Setianingsih, E. S., \& Sulianto, J. (2019). Dampak Penggunaan Gadget terhadap Perkembangan Psikologi pada Anak Sekolah Dasar. Jurnal IImiah Sekolah Dasar, 3(4), 538. https://doi.org/10.23887/jisd.v3i4.22310.

(C) 2021 by the authors. Submitted for possible open access publication under the terms and conditions of the Creative Commons Attribution ShareAlike (CC BY SA) license (https://creativecommons.org/licenses/by-sa/4.0/). 